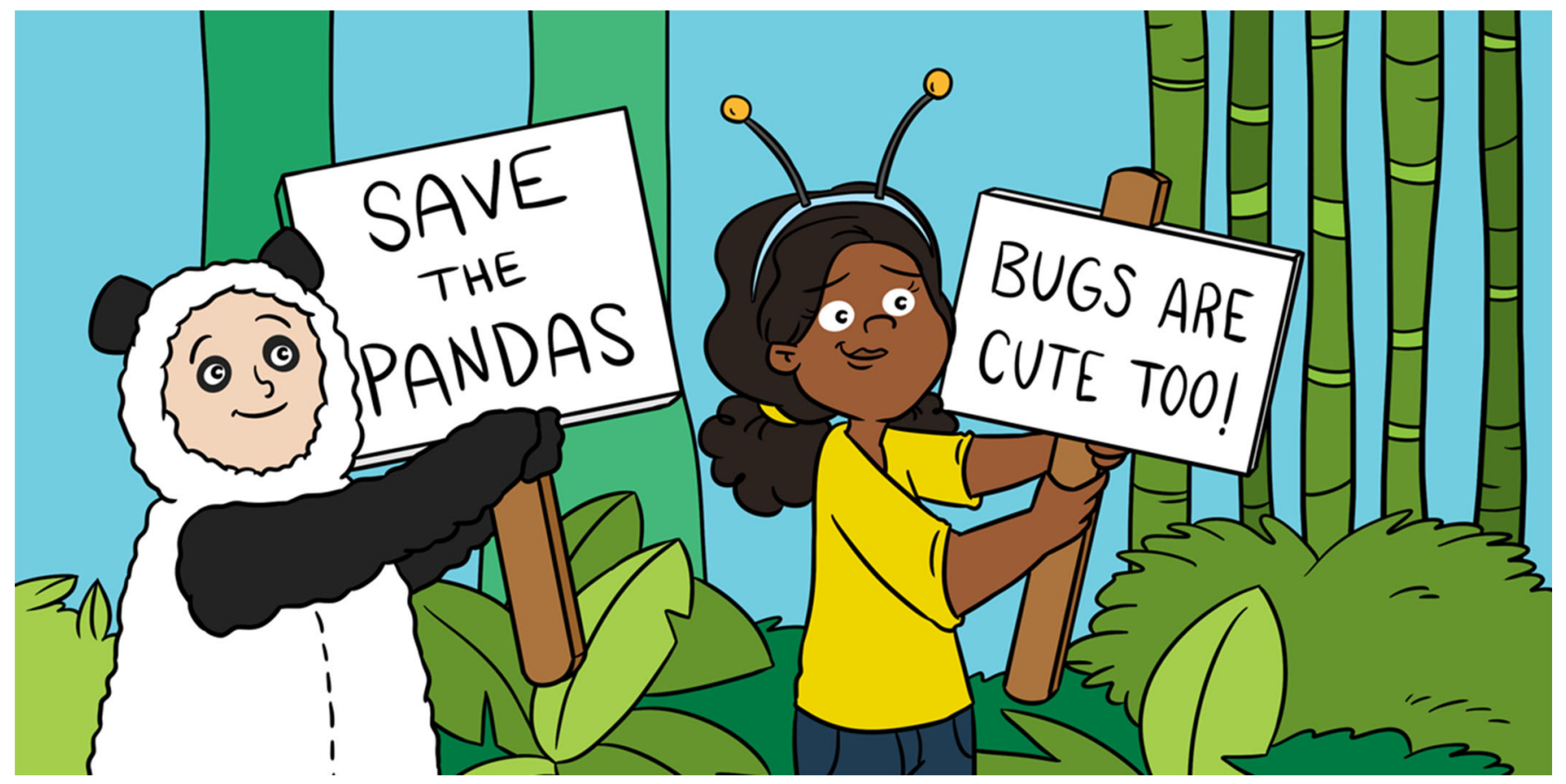

\title{
CAN WE SAVE THE BEAST BY CONSERVING THE BEAUTY?
}

\author{
Felix Gottschall ${ }^{1,2 *}$, Erin K. Cameron ${ }^{3}$, Inês S. Martins ${ }^{4}$, Julia Siebert ${ }^{1,2}$ and Nico Eisenhauer ${ }^{1,2}$ \\ ${ }^{1}$ Experimental Interaction Ecology, German Centre for Integrative Biodiversity Research (iDiv) Halle-Jena-Leipzig, Leipzig, \\ Germany \\ ${ }^{2}$ Institute of Biology, Leipzig University, Leipzig, Germany \\ ${ }^{3}$ Department of Environmental Science, Saint Mary's University, Halifax, Canada \\ ${ }^{4}$ Department of Biology, Leverhulme Centre for Anthropocene Biodiversity, University of York, York, United Kingdom
}

YOUNG REVIEWERS:

ANHAD

AGE: 11

ASHIMA

AGE: 12
Because having a wide variety of species on earth is essential for human health and our economy, conservation areas have been established worldwide. These conservation efforts mostly focus on "beauties," such as pandas or tigers. Many other species are not as charismatic and thus merely considered "beasts." Many "beasts" live invisible lives in the soil but are extremely important for mankind. We asked whether current conservation efforts based on saving the "beauties" can help to automatically protect the "beasts." In other words, is there high biological diversity in the soil at locations with high aboveground biodiversity? We mapped aboveground and belowground biodiversity across the world and found that there are many areas where aboveground biodiversity is high and belowground biodiversity is low, or the other way around. Our results suggest that conserving the "beauties" may not be enough to protect the 
ECOSYSTEM

SERVICES

Functions and processes of an ecosystem that in some way benefit humans. For example, production of fruit, timber, and oxygen, or the purification of water

BIODIVERSITY

Biodiversity describes the variety and variability of life. Depending on the context it can refer to different measures. Most common is the number and variety of different species in a given location.

\section{EXTINCTION}

The permanent disappearance of a species. Extinction can be caused by a natural incidents (dinosaurs) or human actions (dodos).

\section{INTRINSIC VALUE}

A value that is coming from within. Valued for what it is, rather than for what it is worth.

\section{"beasts." We need to consider life belowground when planning new conservation areas.}

\section{WHAT NATURE PROVIDES AND WHY WE NEED IT}

When going for a hike in nature or a walk in a park, there are many different animals and plants to discover. Singing birds, buzzing bees, and pretty flowers are beautiful by themselves and something we enjoy. Furthermore, they provide important functions to our ecosystem and services for us as humans (which are called ecosystem services). For instance, birds can control pests like aphids, and plants provide us with necessary oxygen while also producing food, with the help of bees that spread pollen. The amount and extent of these functions and ecosystem services strongly depends on the variety of different plant and animal species. This variety is referred to as biodiversity [1].

Many plant and animal species worldwide are threatened by human activities. Increasing agriculture, deforestation, and climate change due to excessive use of fossil fuels have pushed many species to extinction [2]. This loss of species is not only worrying in terms of the intrinsic value of nature, but also because we depend on nature's services. With ongoing loss of species, we will not only lose parts of the beauty of nature, but also many of its functions that are essential for human life on earth [3].

\section{THE PROTECTION OF NATURE'S BEAUTY AND SERVICES}

By actively protecting certain areas of the world [4], we support threatened species, preserving them and their services for us and for future generations. When deciding which areas to protect, we often chose regions with especially charismatic and noticeable "beauties," like pandas, tigers, or golden eagles. These species often need a large, high-quality living area and live in regions that contain a high diversity of other species. By protecting these "beauties," it is assumed that a lot of other, smaller animals and plants are also automatically protected and cared for. People are more willing to invest money in "beauties" because everybody knows and loves them. Who does not like to watch a panda rolling around in the forest?

\section{THE BEASTS BELOW US AND WHY THEY ARE OFTEN OVERLOOKED}

However, everybody who has done some gardening work or explored the soil below their feet knows that nature provides shelter to more species than we can see at first glance. Below our feet and the feet 
of the panda lies a hidden community of earthworms, ants, spiders, springtails, centipedes, and beetles. If we look even closer (e.g., with a microscope) there are tiny bacteria and fungi in the soil as well. Like birds, flowers, and bees, all these belowground species fulfill important functions and services. For example, fungi and springtails digest wood and leaves, providing nutrients to the soil and plants. Earthworms loosen the soil and allow air to enter the ground, making it more productive. Centipedes and spiders control pests and thereby prevent pest species from taking over.

Although belowground species fulfill vital roles and provide important services, they are often overlooked. Scientists are just starting to understand how many species there are in the soil and how these species work together in different ways to shape belowground processes. There are several reasons for this lack of knowledge. Soil is not easy to access (or to see through), which makes experiments, monitoring, and observational studies hard to plan and conduct. Furthermore, many important players in belowground systems are tiny and do their work in secret. Some people even consider soil animals as "beasts." Worms, insects, spiders, bacteria, and fungi are rarely considered "beauties," although their alien appearances and ways of life hold their own kind of charm. During the establishment of new protected areas, however, these issues lead to belowground species being left out of consideration.

\section{CAN WE SAVE THE "BEAST" BY PROTECTING THE "BEAUTY"?}

In our research, we asked whether we would automatically protect the important belowground "beasts" like earthworms by choosing protected areas based on aboveground "beauties" like the panda. Can we save the "beast" by protecting the "beauty"?

This question is very important because it helps us to understand whether the current way of choosing protected areas is good enough, or if it has to be adjusted to include ecosystem services that may have been overlooked so far, but are essential for human well-being.

\section{PUBLIC DATABASE}

An organized collection of data that can be accessed by scientists or the general public from all over the world

\section{HOW DID WE APPROACH THIS QUESTION AND WHAT DID WE FIND?}

To determine whether protecting aboveground species also automatically protects belowground species, we assembled big sets of data about the presence and diversity of aboveground species (mammals, birds, amphibians, and plants) and belowground species (bacteria, fungi, and soil animals). Most of the data was already collected and published by collaborating scientists and some information was extracted from public databases [5]. We then used 
Figure 1

Global map showing the distribution and overlap of aboveground (mammals, birds, amphibians, and plants) and belowground

(fungi, bacteria, insects, and worms) biodiversity. Colors indicate different combinations of above- and belowground biodiversity. Orange: high aboveground biodiversity and low belowground biodiversity; beige: low aboveground biodiversity and low belowground biodiversity; green: high aboveground biodiversity and high belowground biodiversity; turquoise: low aboveground biodiversity and high belowground biodiversity; and gray: no data available. From this map, you can see that there are big areas of mismatch (orange), where it is not possible to protect the "beasts" by protecting the "beauties."

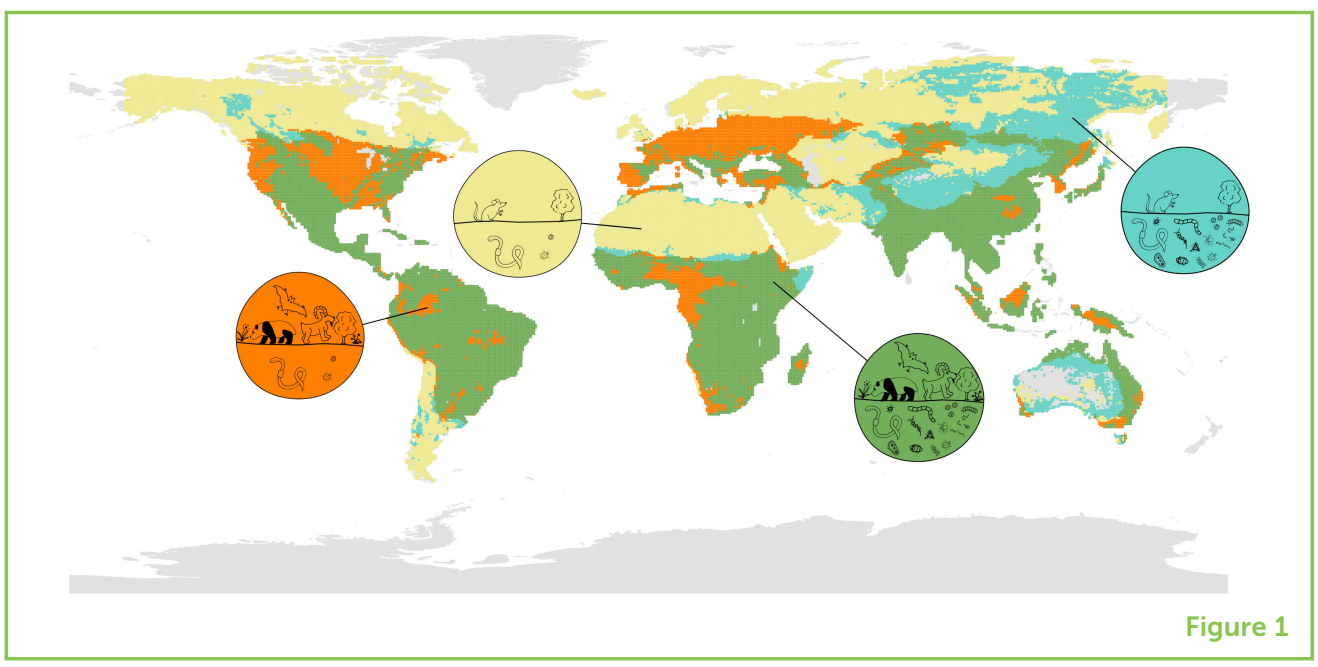

special computer techniques (ArcGIS: a software used to create maps and analyze geographic information) to create maps to show patterns in the data around the globe. By analyzing and comparing these maps, we were able to answer our question.

What is the answer? With the help of our maps (Figure 1), we saw that there are many areas where both aboveground biodiversity and belowground biodiversity are high ("match"), such as in many tropical regions of the globe (Figure 1-green areas). However, we also saw that there are many areas where aboveground biodiversity is high and belowground biodiversity is low (Figure 1-orange areas), or the other way around (Figure 1-turquoise areas) ("mismatch"). One example of high belowground biodiversity but low aboveground biodiversity is the northern regions of the earth, like the vast tundra and boreal regions in the northern hemisphere. The overall area of mismatch, where it is not possible to protect the "beasts" (belowground diversity) simply by protecting the "beauties" (aboveground diversity) spans roughly one third of the land surface of the Earth.

\section{WHAT ABOUT THE FUTURE?}

Given our results, we strongly suggest that we need to adapt the way experts decide which regions to declare as protected areas (Figure 2). While it is very important to protect the habitat of "beauties" like the panda or tiger, we have to be careful not to overlook the "beasts" in the soil that are so important for our well-being. If we only focus on the areas containing "beauties," we risk losing many soil species and their services (examples: soil carbon storage, water purification, nutrient cycling), because these soil species may be very diverse in regions of the world where "beauties" are less diverse.

The results of this study only mark the beginning of new approaches to nature conservation. Since soil is not easily accessible, we still 


\section{Figure 2}

How do we decide which areas to protect? Left: A scientist checks aboveground to see if the area is worth protecting. The decision is based on diversity of aboveground species and occurrence of "beauties". A positive outcome leads to the protection of the area and ecosystem. Middle: A scientist checks and finds low aboveground diversity and is unaware of belowground diversity. The area does not get protected. Soil organisms are overlooked and threatened by industry and agriculture. Important functions and services of soil life are lost. Right: In addition to the aboveground check, scientists also consider soil organisms. The area will be protected based on the positive results for soil diversity. The ecosystem and the soil functions and services are preserved.

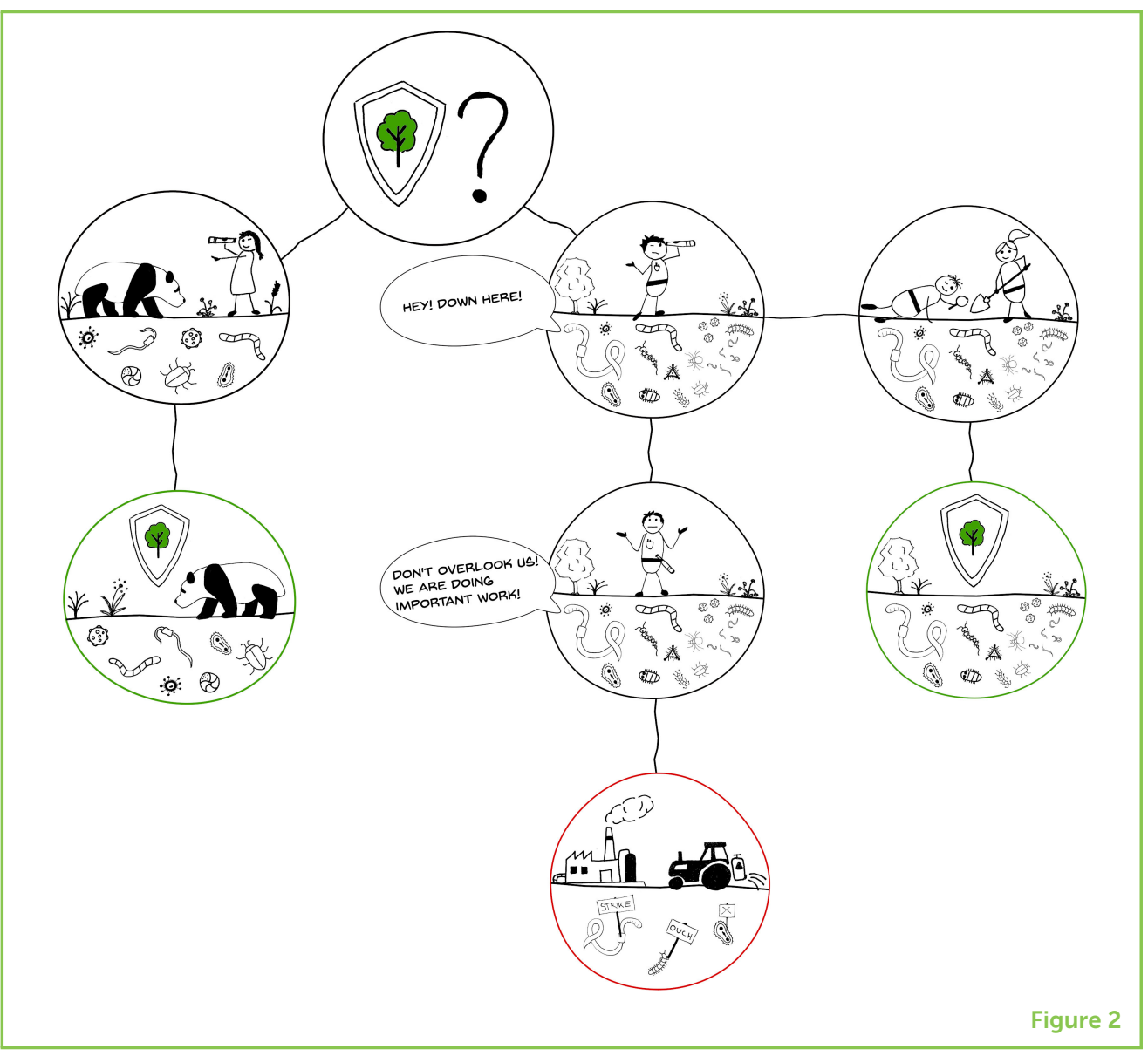

need much more information on threats to belowground processes and soil organisms, as well as on the roles, needs, and behaviors of these organisms. This will help to make recommendations for areas to protect and a general adjustment of common industrial and agricultural practices outside of conservation areas. Therefore, an important next step is to increase the overall knowledge about soil species worldwide, by conducting surveys and monitoring programs. Basically, that means that we have to "dig deeper"! To enable scientists to do this important work, it is essential to raise awareness among both the general public and governments about the importance of the curious "beasts" below our feet.

\section{ORIGINAL SOURCE ARTICLE}

Cameron, E. K., Martins, I. S., Lavelle, P., Mathieu, J., Tedersoo, L., Bahram, M., et al. 2019. Global mismatches in aboveground and belowground biodiversity. Conserv. Biol. 33:1187-92. doi: 10.1111/cobi.13311 


\section{REFERENCES}

1. Merritt, M., Maldaner, M. E., and de Almeida, A. M. R. 2019. What are biodiversity hotspots? Front. Young Minds 7:29. doi: 10.3389/frym.2019.00029

2. IPBES. 2019. Summary for Policymakers of the Global Assessment Report on Biodiversity and Ecosystem Services of the Intergovernmental Science-Policy Platform on Biodiversity and Ecosystem Services. Bonn: IPBES Secretariat.

3. Cardinale, B. J., Duffy, J. E., Gonzalez, A., Hooper, D. U., Perrings, C., Venail, P., et al. 2012. Biodiversity loss and its impact on humanity. Nature 486:59-67. doi: 10.1038/nature11148

4. UNEP-WCMC, IUCN. 2020. Protected Planet: The World Database on Protected Areas (WDPA). Available online at: www.protectedplanet.net (accessed April 8, 2020).

5. Cameron, E. K., Martins, I. S., Lavelle, P., Mathieu, J., Tedersoo, L., Bahram, M., et al. 2019. Global mismatches in aboveground and belowground biodiversity. Conserv. Biol. 33:1187-92. doi: 10.1111/cobi.13311

SUBMITTED: 31 March 2020; ACCEPTED: 24 August 2020;

PUBLISHED ONLINE: 06 October 2020.

EDITED BY: Malte Jochum, German Centre for Integrative Biodiversity Research (iDiv), Germany

CITATION: Gottschall F, Cameron EK, Martins IS, Siebert J and Eisenhauer N (2020) Can We Save the Beast by Conserving the Beauty? Front. Young Minds 8:547740. doi: $10.3389 /$ frym.2020.547740

CONFLICT OF INTEREST: The authors declare that the research was conducted in the absence of any commercial or financial relationships that could be construed as a potential conflict of interest.

COPYRIGHT @ 2020 Gottschall, Cameron, Martins, Siebert and Eisenhauer. This is an open-access article distributed under the terms of the Creative Commons Attribution License (CC BY). The use, distribution or reproduction in other forums is permitted, provided the original author(s) and the copyright owner(s) are credited and that the original publication in this journal is cited, in accordance with accepted academic practice. No use, distribution or reproduction is permitted which does not comply with these terms.

\section{YOUNG REVIEWERS}

\section{ANHAD, AGE: 11}

Hello my name is Anhad and I like writing about topics (sometimes). I also love watching TV and playing video games on my console and also love hanging out with my friends and family. I like watching netflix in my free time and cooking. 


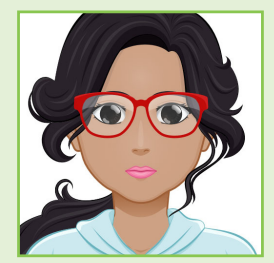

\section{ASHIMA, AGE: 12}

$\mathrm{Hi}$, I am Ashima. I like to read fiction books and swim. I love to study. My favorite subject is mathematics. Quadratic functions are my favorite topic in mathematics.
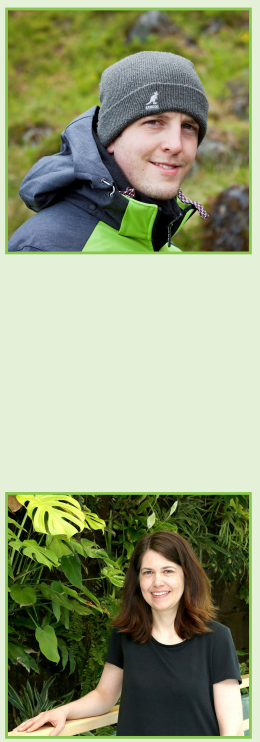

\section{AUTHORS}

\section{FELIX GOTTSCHALL}

Already as a kid, Felix was fascinated by dinosaurs and all kinds of extinct animals. After memorizing all his children's books, he spent a lot of time in museums and imagined how it would be to search for long-lost animals himself. Over time, his interest switched to living animals, like birds (which basically are dinosaurs!), and he began to study biology. As a scientist, he has worked on many different topics, from glowing snails over thirsty treetops to life below ground. Instead of digging for dinosaurs, he is now digging for soil bacteria and still sees the adventure in it. *fgottschall@gmail.com

\section{ERIN K. CAMERON}

Erin enjoyed playing outside as a child but did not consider becoming a biologist. Eventually, she started helping with research examining how human activities affect songbirds and she found it fascinating. Once she started to work on soil organisms and saw how much is still unknown about them, she was convinced that she wanted to study biology. Now she investigates how human activities affect soil biodiversity and the functioning of ecosystems. Erin also enjoys cross-country skiing, bicycling, and kayaking in her free time.
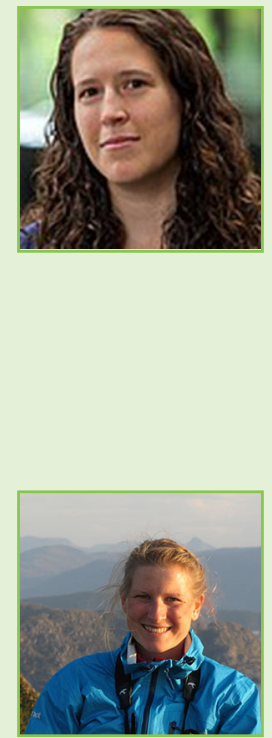

\section{INÊS S. MARTINS}

Inês always loved learning how things are created, where they came from, and how they are changing. Nothing holds more questions like that than nature, so it is not surprising Inês choose to pursue biology in school. While studying, she became particularly interested in looking at how humans have been influencing organisms by changing their habitats. Now, she spends her days trying to model and understand how biodiversity responds to past and possible future environmental changes across vast areas of the world. Outside work, Inês likes to play sports, go to the cinema, and to simply enjoy time with friends and family.

\section{JULIA SIEBERT}

Julia has been fascinated by nature since she was a child. She spent as much time as possible outdoors, built moss houses in the forest, and searched for all kinds of animals. She followed this passion by studying biology and communication science and was always keen on finding ways to transfer knowledge to different audiences. Her scientific studies focused on the effects of global change on soil organisms and their ecosystem functions in agroecosystems. Furthermore, she explored ways to engage school students in biodiversity science. In her free time, she enjoys horse-riding, traveling, birdwatching, mountain biking, and all sorts of outdoor sports. 


\section{NICO EISENHAUER}

Nico has been interested in nature since his early childhood. He dug for earthworms, caught frogs and fish, and helped lizards survive the winter months. He has always been fascinated by the beauty of nature and driven by the question of why a specific plant or animal species occurs at one place but not at another place. During his study of biology, he discovered his interest in soil animals and their important activities that are crucial for the functioning of ecosystems. When not at work, Nico likes to play soccer and badminton, to run, and to spend time with his family and friends. 